University of Nebraska - Lincoln

DigitalCommons@University of Nebraska - Lincoln

DIETARY WHEAT GERM OIL INFLUENCES GENE EXPRESSION IN LARVAE AND EGGS OF THE ORIENTAL FRUIT FLY

Thomas A. Coudron

USDA Agricultural Research Service, tom.coudron@ars.usda.gov

Chiou Ling Chang

USDA Agricultural Research Service

Cynthia L. Goodman

USDA Agricultural Research Service

David Stanley

USDA Agricultural Research Service

Follow this and additional works at: https://digitalcommons.unl.edu/usdaarsfacpub

Part of the Agricultural Science Commons

Coudron, Thomas A.; Chang, Chiou Ling; Goodman, Cynthia L.; and Stanley, David, "DIETARY WHEAT GERM OIL INFLUENCES GENE EXPRESSION IN LARVAE AND EGGS OF THE ORIENTAL FRUIT FLY" (2011). Publications from USDA-ARS / UNL Faculty. 558.

https://digitalcommons.unl.edu/usdaarsfacpub/558

This Article is brought to you for free and open access by the U.S. Department of Agriculture: Agricultural Research Service, Lincoln, Nebraska at DigitalCommons@University of Nebraska - Lincoln. It has been accepted for inclusion in Publications from USDA-ARS / UNL Faculty by an authorized administrator of DigitalCommons@University of Nebraska - Lincoln. 


\section{DIETARY WHEAT GERM OIL INFLUENCES GENE EXPRESSION IN LARVAE AND EGGS OF THE ORIENTAL FRUIT FLY}

\section{Thomas A. Coudron}

USDA Agricultural Research Service, Biological Control of Insects Research Laboratory, Columbia, Missouri

\section{Chiou Ling Chang}

USDA Agricultural Research Service, U.S. Pacific Basin Agricultural Research Center, Hilo, Hawaii

\section{Cynthia L. Goodman and David Stanley}

USDA Agricultural Research Service, Biological Control of Insects Research Laboratory, Columbia, Missouri

Changes in animal nutrition, particularly essential dietary components, alter global gene expression patterns. Our goal is to identify molecular markers that serve as early indicators of the quality of insect culture media. Markers of deficient culture media will increase the efficiency of developing optimal systems for mass rearing beneficial insects and some pest species because decisions on culture media quality can be made without waiting through one or several life cycles. The objective of our current study is to discover molecular markers of essential dietary lipid deficiency in the oriental fruit fly, Bactrocera dorsalis. We reared groups of fruit flies separately on media either devoid of or supplemented with wheat germ oil (WGO) and analyzed gene expression in third instar larvae and $F_{1}$ eggs using $2 D$ electrophoresis. Gel densitometry revealed significant changes in expression levels of genes encoding eight proteins in larvae and 22 proteins in eggs. We identified these proteins by using mass spectrometry (MALDI TOF/TOF) and bioinformatic analyses of the protein sequences. Among these, we identified one gene encoding the receptor of activated $C$ Kinase 1 (RACK1) that increased in expression by 6.8-fold in eggs from adults that were reared as larvae on media

Correspondence to: Thomas A. Coudron, USDA-Agricultural Research Service, 1503 South Providence Road, Columbia, MO 65203. E-mail: tom.coudron@ars.usda.gov

ARCHIVES OF INSECT BIOCHEMISTRY AND PHYSIOLOGY, Vol. 76, No. 2, 67-82 (2011)

Published online in Wiley Online Library (wileyonlinelibrary.com).

(c) 2010 Wiley Periodicals, Inc. DOI: 10.1002/arch.20398 
supplemented with WGO. RACK1 is an essential component of at least three intracellular signal transduction pathways, making it a good molecular marker candidate of lipid deficiency in fruit flies and possibly many other insect species. (C) 2010 Wiley Periodicals, Inc.

Keywords: wheat germ oil; fruit fly diet; Bactrocera dorsalis; proteomics

\section{INTRODUCTION}

Sterile insect technique used in the control of the oriental fruit fly, Bactrocera dorsalis, requires continuous mass rearing (Parker, 2005). As seen in the highly successful experience with screwworm eradication project, formulation of an economically and biologically effective culture system for screwworm larvae required decades of research. The lengthy research program is due in part to the length of the insect life cycle and the need to conduct nutritional research over several consecutive generations. It may require an entire year to evaluate a single change in a culture medium. The efficiency of the process could be improved by the discovery of molecular markers of nutritional deficiency that are present in the egg or early larval stage of development, which could be used to make decisions on media quality without waiting through one or more insect life cycles. Diet influences gene expression in insects (Yocum et al., 2006). Our goal is to identify early molecular markers of essential nutritional deficiency (Coudron et al., 2006). The intent is to apply those early indicators to direct diet formulation for improving the fitness and reducing the cost of rearing the oriental fruit fly.

The addition of wheat germ oil (WGO) to a liquid fruit fly diet enhanced rearing efficiency by significantly improving several parameters of biological fitness. Larval development, pupal recovery, percentage of adult fliers, egg production, and hatch were improved, most likely because WGO provides substantial quantities of essential polyunsaturated fatty acids (Dadd, 1985; Chang and Vargas, 2007; Chang, 2009). The positive nutritional influence of WGO or other sources of polyunsaturated fatty acids in insect diets has been thoroughly documented (Dadd, 1985). However, it is not clear how dietary WGO benefits insects. One mechanism of dietary WGO action in fruit fly larvae is its influence on gene expression in mature adults (Chang et al., 2010). Dietary WGO led to enhanced expression of some genes and to decreased expression of others.

Given evidence that dietary WGO influenced gene expression in adult fruit flies, we posed the hypothesis that dietary WGO would also influence gene expression in larvae and subsequent $\mathrm{F}_{1}$ egg stages. In this study, we report on the outcomes of experiments designed to test our hypothesis.

\section{MATERIAL AND METHODS}

\section{Insects and Sample Collection}

Newly collected eggs ( $<6 \mathrm{hr}$ ) of oriental fruit fly, B. dorsalis (Hendel) were provided by the Tropical Crop and Commodity Protection Research Unit of the USDA's Agricultural Research Service (ARS) in Honolulu, Hawaii and maintained as previously described (Chang et al., 2010). B. dorsalis larvae were reared on a liquid diet devoid of, or separately supplemented with, WGO (0.66\%, v:v) (Chang and Vargas, 2007). Adults from both larval diets were maintained on a mixture of sugar:protein hydrolysate 
(3:1, wt:wt) (Chang et al., 2004). Samples included third instar larvae and $\mathrm{F}_{1}$ eggs laid by adults that developed from larvae reared on each of these diets.

\section{Sample Preparation}

Samples were homogenized $3 \times 15 \mathrm{sec}$ on ice in $10 \mathrm{mM}$ Tris-HCl (pH7.0) containing protease inhibitors (final dilution $=1: 100$; Sigma, St. Louis, MO, \# P8340 for Mammalian Cell and Tissue Extracts) using a Tissue Master (Omni Intl., Marietta, GA). Homogenates were centrifuged twice at $15,294 \times g$ for $15 \mathrm{~min}$ at $4^{\circ} \mathrm{C}$. The middle layer of homogenized samples was retained and transferred to new vials on ice for immediate use. Three independent biological replicates were processed for each treatment.

\section{D-Electrophoresis}

Electrophoresis and mass spectrometric protocols followed published procedures (Stanley et al., 2008). Protein amounts were determined using the Pierce Micro BCA Protein Assay Kit, using BSA as a quantitative standard (Rockford, IL). Protein samples were prepared for iso-electric focusing (IEF), as previously described (Chang et al., 2010). IEF was performed with a Protean IEF cell system (Bio-Rad, Hercules, CA) using the standard protocol and a pre-set linear volt ramp program $(8,000 \mathrm{~V}$ and $50 \mu \mathrm{A} /$ strip max., $35,000 \mathrm{vH})$.

For the second dimension, the IPG strips were prepared and subjected to SDSPAGE using the Criterion Cell system (Bio-Rad $\# 165-6001)$ with a precast gel (8-16\% Tris-HCl for egg samples and 4-15\% Tris-HCl for larval samples; Bio-Rad). Gels were stained with Coommassie Blue G-250 (BioSafe Stain; Bio-Rad) and analyzed using Delta 2D software (Decodon GmbH, Greifswald, Germany). Protein spots with densities significantly different between treatments (Students' $t$-test, $P<0.05$ ) were removed using a 1.5-mm spot picker (The Gel Company, San Francisco, CA) and stored at $-80^{\circ} \mathrm{C}$. One gel was run for each independent biological replicate.

\section{MS/MS Analysis}

Proteins were digested with trypsin and prepared for MS/MS analysis as previously described (Stanley et al., 2008). A portion of each protein was mixed with alpha-cyano4-hydroxycinnamic acid matrix and applied to the MALDI target and analyzed. The resulting sequence data, combined with observed MW and pI values, were used to establish protein identities. Sequences generated from these analyses were used to interrogate NCBI-BLAST for protein matches (using the PAM30 matrix and searching within "Metazoa"). E-values and frequency of matches to a specific protein were the primary criteria for these determinations.

\section{Quantitative Real-Time PCR}

Total RNA was isolated from fly tissues using the TRIzol Reagent (Invitrogen, Carlsbad, CA) following the manufacturer's protocol. RNA concentrations were measured at $260 \mathrm{~nm}$ on a Nanodrop 2000 spectrophotometer (Thermo Scientific, Waltham, MA). The extracted total RNA was treated with RNase-free DNase I (Promega, Madison, WI, \# M6101). The first-strand cDNA was synthesized from $3 \mu \mathrm{g}$ total RNA using Oligo(dT) primers and superscript II reverse transcriptase (Invitrogen) according to the manufacturer's protocol. 
Real-time PCR (RT-PCR) amplification and analysis were performed on the Eppendorf Master Cycle Rep Realplex $4 \mathrm{~S}$ and analyzed with the Realplex software (Eppendorf, Hauppauge, NY). RT-PCR was carried out using Absolute QPCR SYBR Green kit (Thermo Scientific, Pittsburg, PA) according to the manufacturer's procedure in $20 \mu \mathrm{l}$ reaction volumes. The RT-PCR program used was: hold at $95^{\circ} \mathrm{C}$ for $15 \mathrm{~min}$ followed by 50 cycles at $95^{\circ} \mathrm{C}$ for $15 \mathrm{sec}, 52^{\circ} \mathrm{C}$ for $30 \mathrm{sec}$, then $72^{\circ} \mathrm{C}$ for $30 \mathrm{sec}$. The specificity of the SYBR Green PCR signal was further confirmed by melting curve analysis. The mRNA expression was quantified using the comparative CT (cross threshold, the PCR cycle number that crosses the signal threshold) method (Livak and Schmittgen, 2001). The cDNA was amplified using gene-specific primers. The primers for protein spot E17 were

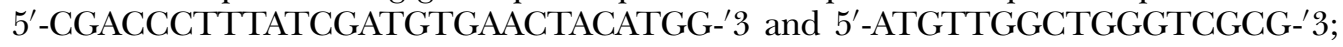
primers for protein spot E20 were 5'-GCTACAAGGCAGCAAGTTC- ${ }^{\prime} 3$ and 5'-GAGAACTTCAAGCTGAAGCACTA-' 3 . To normalize the cDNA, the primers for the housekeeping gene actin (5-TCCATCATGAAGTGCGACGT-'3 and 5'-AGAAGCACTTGCGGTGGACGA-' 3 ) were also used to amplify cDNA from the samples.

The values generated for quantitative real-time PCR represent the mean and standard error of the ratio of the quantity of selected mRNA for treatments with WGO/ without WGO, for six independent replications. All the data are presented as mean \pm standard errors. Data were analyzed by Students' $t$-test utilizing NCSS 2007 (Kaysville, UT).

\section{RESULTS}

Representative 2D protein gels are presented in Figure 1 for third instar larvae reared on each of the diets and in Figure 2 for $F_{1}$ eggs laid by adults from the larvae reared on each of the diets. Quantitative gel analysis detected approximately 380 spots/gel from larval preparations for each treatment and over 800 proteins from egg preparations. Gel densitometry revealed changes, by 2-fold or more, in expression of genes encoding eight larval proteins and 43 egg proteins. These spots were selected for digestion and analysis by MALDI-TOF MS/MS. We identified eight larval proteins and 23 egg proteins by in silico analysis.

Media supplemented with WGO led to decreased expression of eight genes in larvae. Genes encoding larval proteins L-10, L-16, L-26, L-22, and L-21 were downregulated by approximately $50 \%$ and the remaining three genes were downregulated by 20-40\% (Tables 1 and 2). Protein functions affected included those involved in protein degradation and folding, signal transduction, and cell protection.

For $\mathrm{F}_{1}$ eggs, larval media supplemented with WGO led to up- and downregulation of gene expression. WGO influenced the expression of genes encoding proteins involved with protein metabolism, structure and function, signal transduction, cell protection, DNA replication and repair, energy and metabolism, intracellular signaling, and lipid transport (Tables 3 and 4). Genes encoding proteins E-06, E-08, E-68, E-98, and E-93 were upregulated by twofold or more. WGO also led to downregulation of several genes.

We designed primers to genes corresponding to two proteins (E-17 and E-20; Fig. 3) that changed in expression on analysis of 2-D gels. Genes were selected on the basis of their overall expression level and efficiency of design. We used these primers to confirm parallel changes in protein spot densities and mRNA expression. For both 

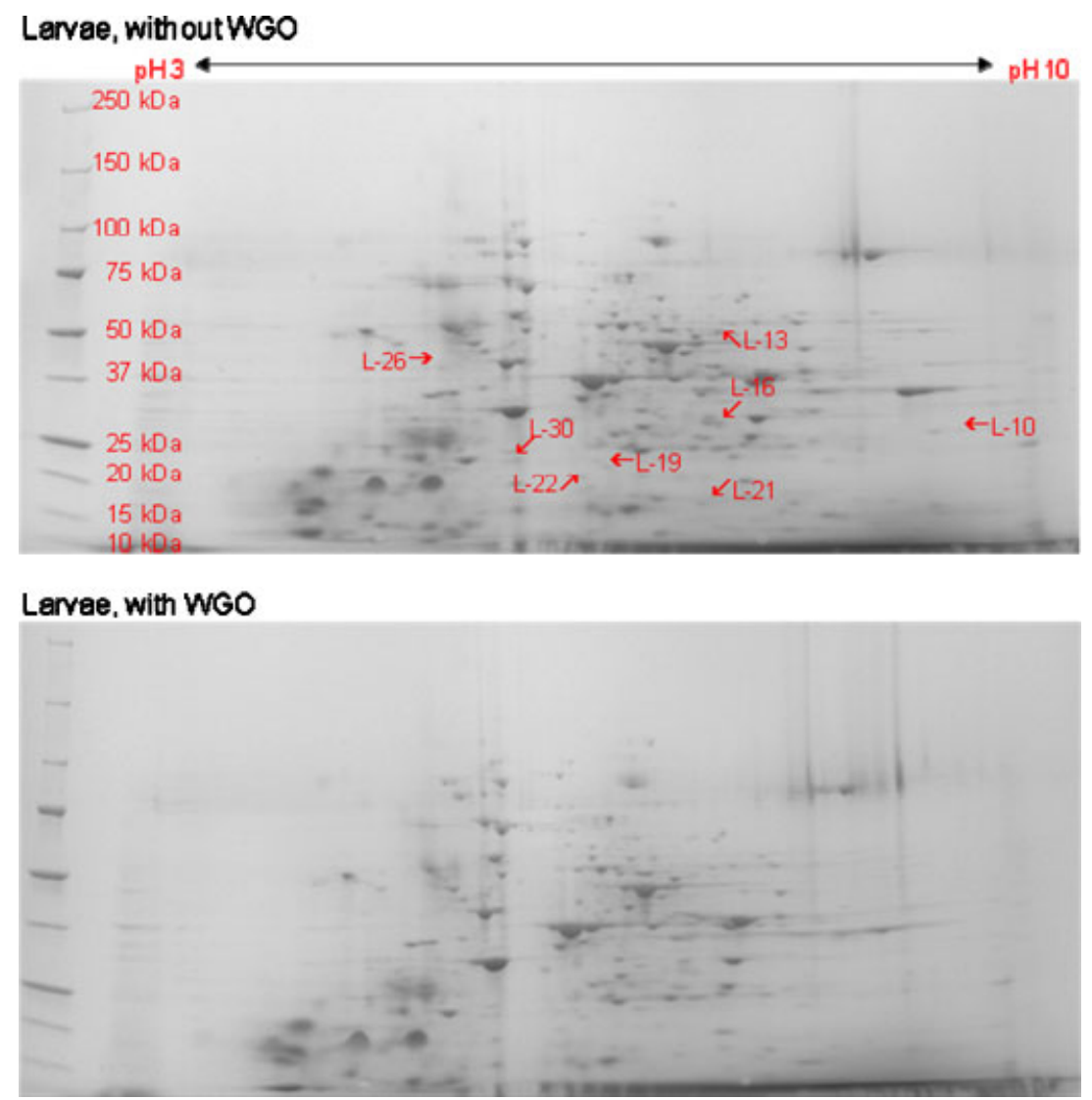

Figure 1. Representative 2D gels showing the influence of dietary WGO on protein expression in larvae reared on diet with and without WGO. The labeled spots in this image were selected for extraction and MS/MS analysis. WGO, wheat germ oil.

proteins, mRNA and protein levels were lower in eggs oviposited by adults that were reared on diet supplemented with WGO during the larval stage.

\section{DISCUSSION}

The data reported in this paper strongly support our hypothesis that supplementing larval fruit fly culture medium with WGO influences gene expression, recorded by changes in whole-organism cellular protein profiles, in third instar larvae and subsequent $\mathrm{F}_{1}$ eggs. The influence of dietary WGO, which we attribute to essential polyunsaturated fatty acids, on gene expression can be registered without first separating the genders, even in juvenile insects. We did not determine the gender of larvae and $F_{1}$ eggs and the changes in gene expression we recorded represent up- and downregulating influences for unknown proportions of males and females. This is a valuable finding because determining gender can be a difficult and resource consuming exercise. Our discovery that changes in nutritional quality influence gene expression in egg and larval stages supports efforts to find molecular markers of nutritional deficiency at early developmental stages. 


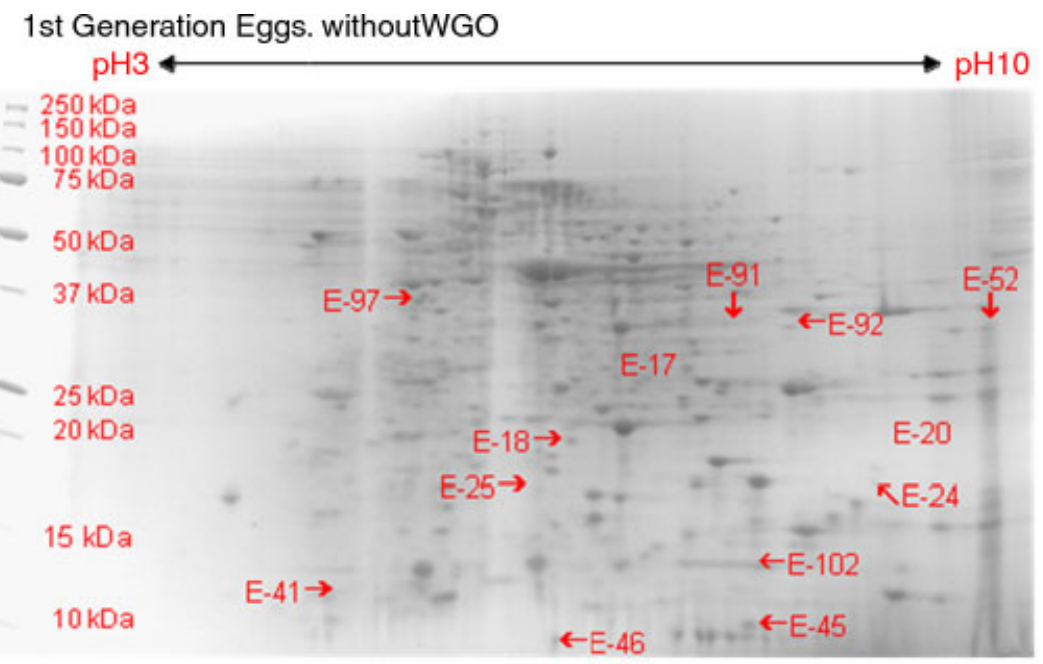

$1^{\text {st }}$ Generation Eggs. with WGO

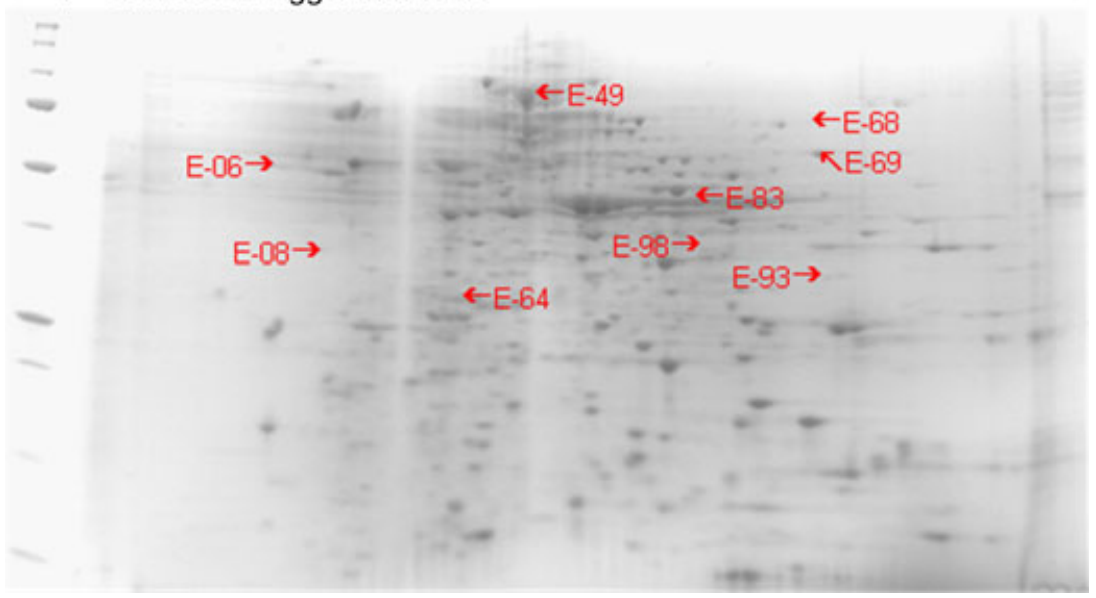

Figure 2. Representative 2D gels showing the influence of dietary WGO on protein expression in eggs oviposited by adults from larvae reared on diet with and without WGO. The labeled spots in this image were selected for extraction and MS/MS analysis. WGO, wheat germ oil.

WGO influenced the expression of more genes during the $\mathrm{F}_{1}$ egg stage than the third instar larvae taken directly from the WGO-supplemented medium. It also exerted larger influences on gene expression in eggs than in larvae. WGO supplementation in the larval diet resulted in downregulation of several genes in the third instar larvae. We speculate that lower expression in lipid-rich larvae relative to larvae taken from the lipid-deficient medium indicates a greater need for these eight proteins, and possibly others, in larvae reared on lipid-deficient diets. We now turn to discussion of a few selected genes, those that changed in expression by at least 2-fold.

For larvae, only L-10 changed in expression level by twofold or more. This protein corresponds to protein M-57 (Male 57; declined by 20\%) in our previous paper (Chang et al., 2010). L-10 (and M-57) is a member of the 70-kDa heat shock proteins 


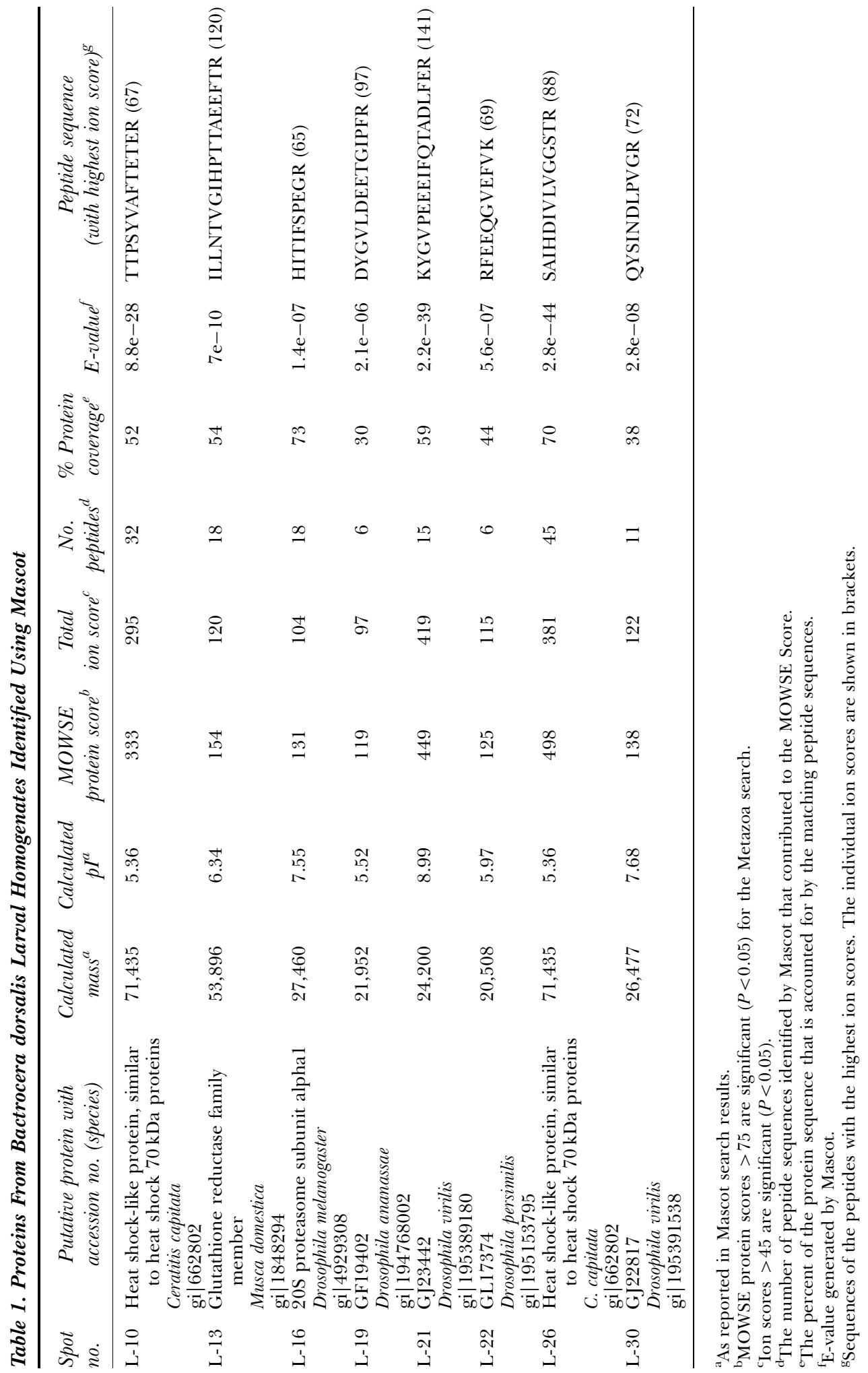


Table 2. Relative Changes in Gene Expression and Function of Proteins Identified by MS/MS From Larvae Fed on Diet With or Without Wheat Germ Oil (+WGO or -WGO, respectively)

\begin{tabular}{|c|c|c|}
\hline Spot no. & $+W G O /-W G O$ ratio & Protein function \\
\hline \multicolumn{3}{|c|}{ Protein structure, function and degradation } \\
\hline $\mathrm{L}-10$ & 0.47 & Involved in protein folding and signal transduction \\
\hline $\mathrm{L}-16$ & 0.56 & Involved in nonlysosomal protein degradation \\
\hline L-26 & 0.55 & Involved in protein folding and signal transduction \\
\hline \multicolumn{3}{|c|}{ Cell protection } \\
\hline L-13 & 0.57 & Catalyzes the reduction of oxidized glutathione \\
\hline L-19 & 0.78 & $\begin{array}{l}\text { Peroxiredoxin: thiol-specific antioxidant protects cells } \\
\text { by reducing hydrogen peroxide, peroxynitrite, } \\
\text { and organic hydroperoxides }\end{array}$ \\
\hline L-22 & 0.55 & $\begin{array}{l}\text { Glyoxalase/Bleomycin resistance protein/Dioxygenase: } \\
\text { detoxifies endogenous toxins }\end{array}$ \\
\hline L-30 & 0.69 & $\begin{array}{l}\text { Peroxiredoxin: reducing hydrogen peroxide, } \\
\text { peroxynitrite, and organic hydroperoxides }\end{array}$ \\
\hline \multicolumn{3}{|c|}{ Signal transduction and cytoskeleton } \\
\hline $\mathrm{L}-21$ & 0.54 & $\begin{array}{l}\text { Actin-binding domain: found in cytoskeletal and } \\
\text { signal transduction proteins }\end{array}$ \\
\hline
\end{tabular}

(HSP), which are ubiquitously expressed and strongly upregulated by heat and other stresses. We infer from the downregulation of this gene that WGO lowered one or more stressors in larval cells. We note relatively few differences in gene expression between the third instar larvae taken from unsupplemented-and WGO-supplemented media. This accords with classical research on insect essential fatty acid requirements (Dadd, 1985). For many insect species, the eggs provide essential fatty acids to the embryonic and early-post embryonic stages and essential fatty acid deficiency does not appear until the pupal/adult molt. In some species, such as the mosquito Culex pipiens, the deficiency does not appear until after the adults emerge and in still other species essential fatty acid deficiency does not appear until the next generation. For the Oriental fruit fly, preliminary results indicate that WGO deficiency does not influence gene expression in newly emerged adults (Chang and Coudron, unpublished observations), but does influence gene expression in 11-day old unmated adults (Chang et al., 2010). We infer from our data on protein spot L-10 that WGO deficiency exerts a subtle stress in fruit fly larvae that increases as the larvae progress through adulthood and egg production.

WGO supplementation led to increased expression of two ubiquitin-associated proteins in $F_{1}$ eggs. Expression of the gene for $26 \mathrm{~S}$ proteasome subunit (spot E-06) increased 5.4-fold. This protein is involved in the ubiquitin-proteasome pathway that degrades most cytosolic and nuclear proteins (Hershko and Ciechanover, 1998). Protein spot E-08, which increased in expression by about 2.5 -fold, is a nascent polypeptide-associated complex protein. These proteins reversibly and specifically bind to ribosomes, where they act in protein folding and targeting (Wegrzyn et al., 2006). Expression increased for two genes encoding proteins associated with energy and metabolism, including aconitate hydratase (E-68) and glyceraldehyde-3-phosphate dehydrogenase (E-98). Aconitate hydratase is an iron-sulfur protein that catalyzes isomerization of citrate to isocitrate via cis-aconitate in the TCA cycle (Beinert et al., 1996) and glyceraldehyde-3-phosphate dehydrogenase catalyzes a step in glycolysis (Fife and Szabo, 1973). The expression of a gene encoding Receptor of Activated C Kinase 1 (RACK1; protein spot E-93) was increased by 6.8 -fold in $\mathrm{F}_{1}$ eggs 


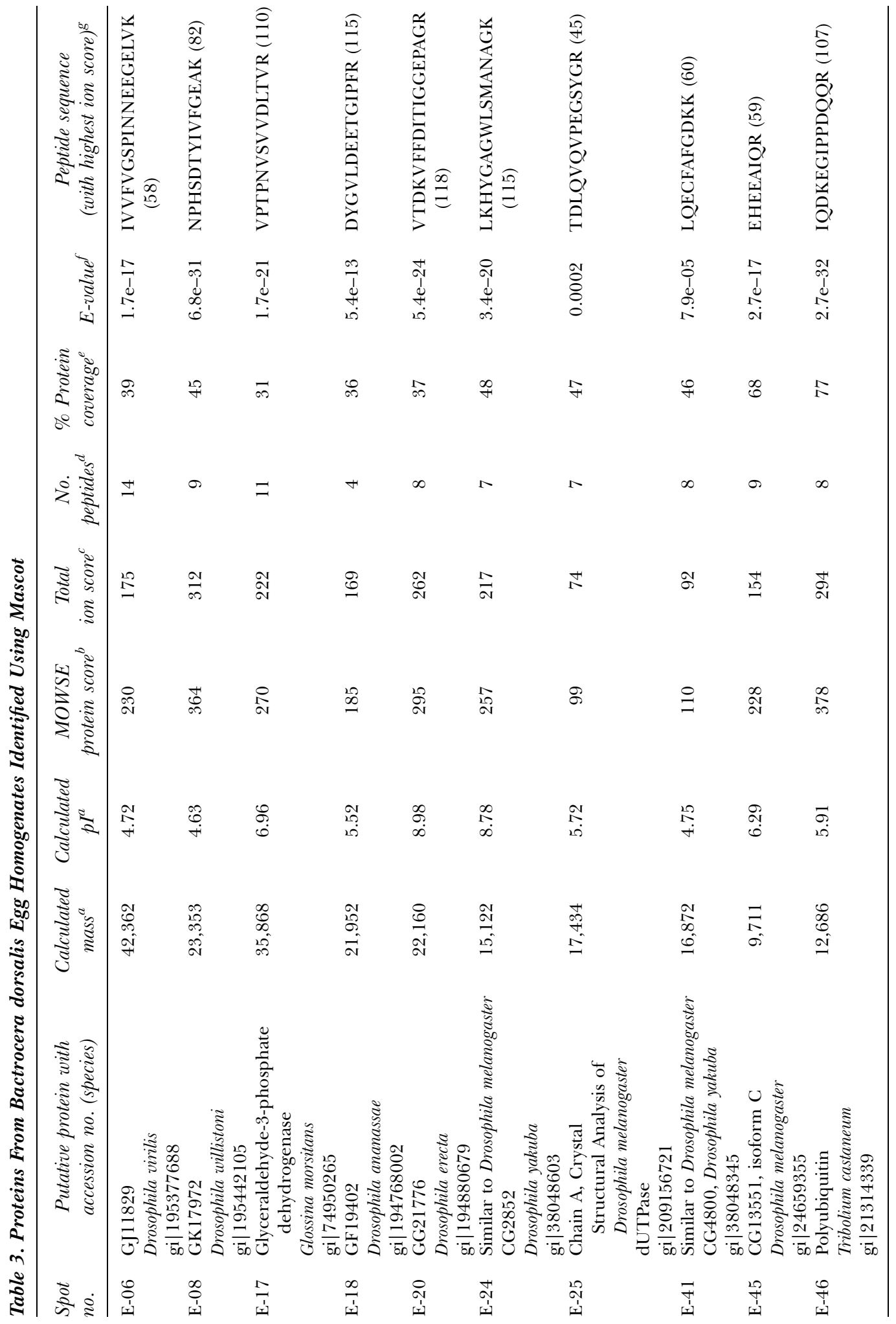




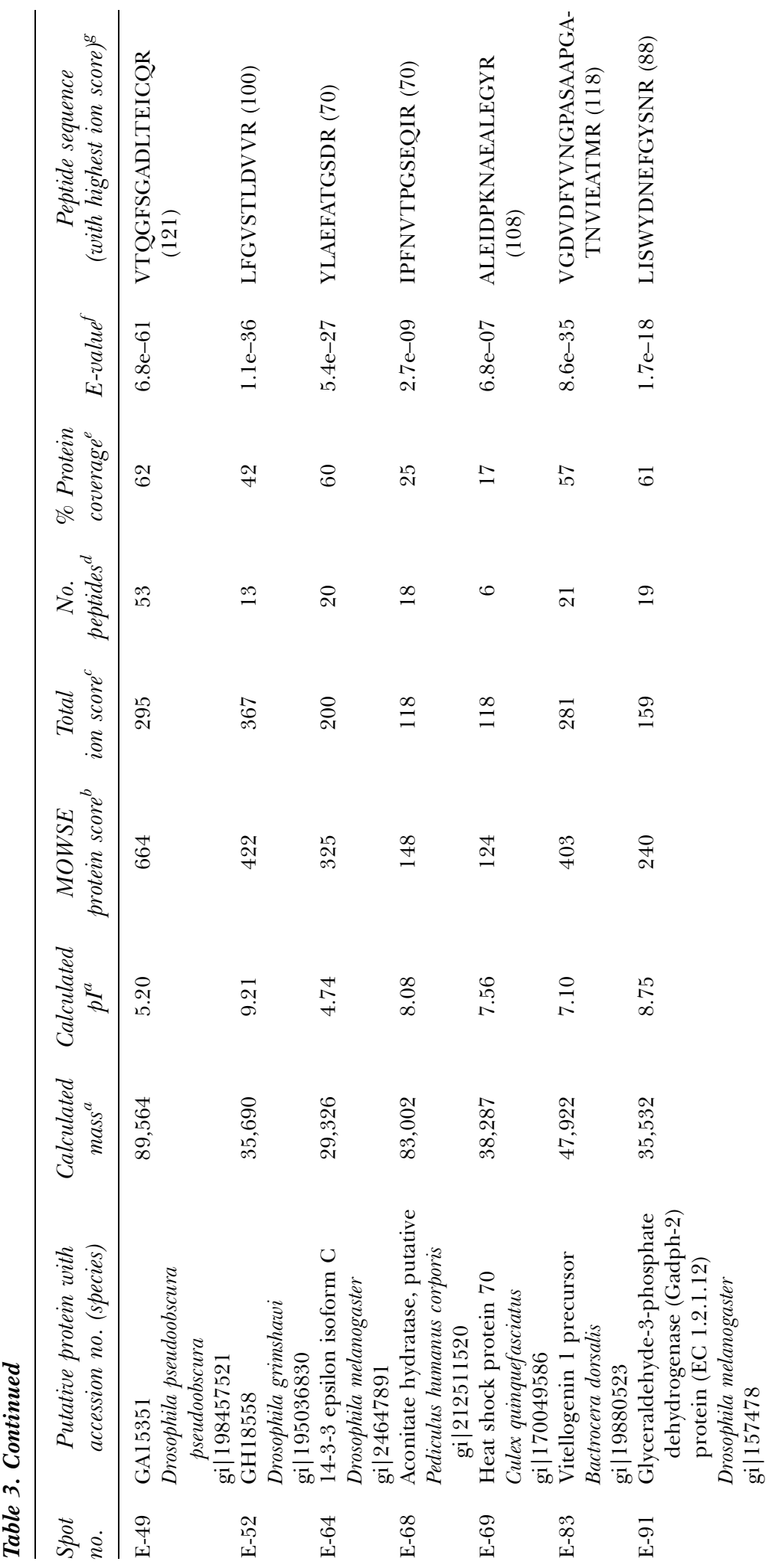




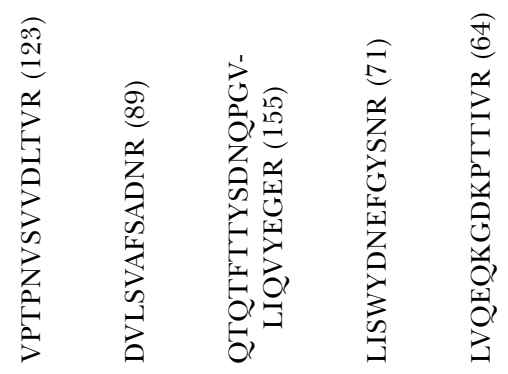

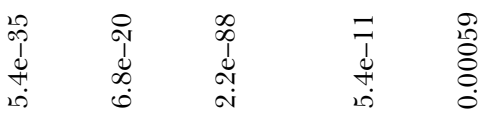

के is 8 के 1

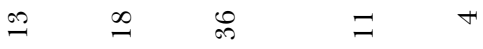

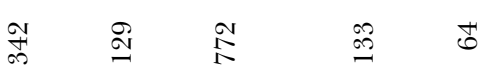

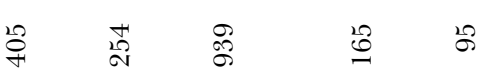

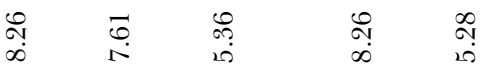

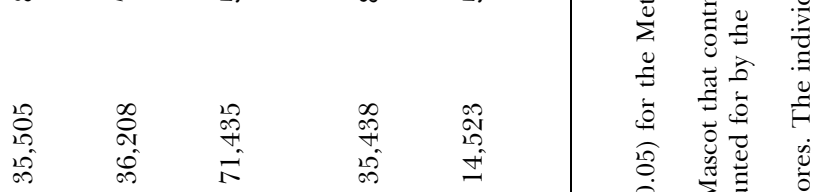

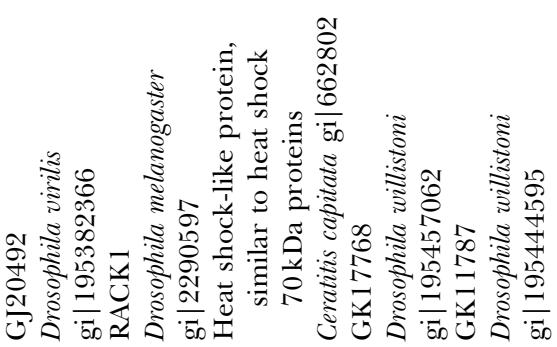

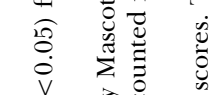

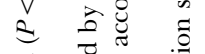

$\vec{\Xi}$.

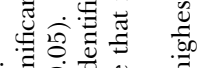

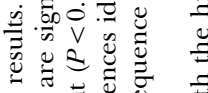

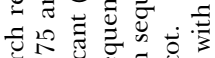

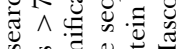

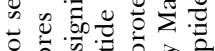

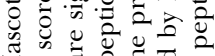

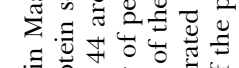

$\exists=$

出

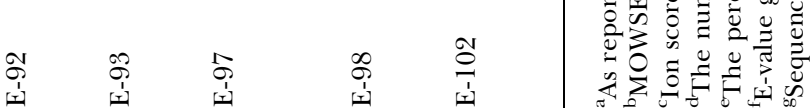


Table 4. Relative Changes in Gene Expression and Function of Proteins Identified by MS/MS of Homogenates of Eggs From Adults that were Reared as Larvae on Diet With or Without Wheat Germ Oil (+WGO or $-W G O$, respectively)

\begin{tabular}{|c|c|c|c|}
\hline Spot no. & $\begin{array}{l}G O /-W \\
\text { ratio }\end{array}$ & t-Test P-value & Function (category) \\
\hline \multicolumn{4}{|c|}{ Energy and metabolism } \\
\hline E-17 & 0.40 & 0.003 & Plays an important role in glycolysis and gluconeogenesis \\
\hline E-45 & 0.23 & 0.010 & $\begin{array}{l}\text { Mitochondrial ATPase inhibitor: involved in the negative } \\
\text { regulation of nucleotide metabolic processing }\end{array}$ \\
\hline E-49 & 1.57 & 0.000 & $\begin{array}{l}\text { AAA + ATPase domain: functions as molecular chaperones, } \\
\text { these domains are often subunits in proteases or helicases }\end{array}$ \\
\hline E-52 & 0.43 & 0.052 & Malate dehydrogenases: important in the TCA cycle \\
\hline E-68 & 2.43 & 0.026 & Plays important role in TCA cycle \\
\hline E-83 & 1.48 & 0.020 & $\begin{array}{l}\text { Major yolk protein, serves as a nutrient source for developing } \\
\text { embryos }\end{array}$ \\
\hline E-91 & 0.44 & 0.003 & $\begin{array}{l}\text { Glyceraldehyde-3-phosphate dehydrogenase: plays an } \\
\text { important role in glycolysis and gluconeogenesis }\end{array}$ \\
\hline E-92 & 0.37 & 0.012 & $\begin{array}{l}\text { Glyceraldehyde-3-phosphate dehydrogenase: plays an } \\
\text { important role in glycolysis and gluconeogenesis }\end{array}$ \\
\hline E-98 & 3.21 & 0.019 & $\begin{array}{l}\text { Glyceraldehyde-3-phosphate dehydrogenase: plays an } \\
\text { important role in glycolysis and gluconeogenesis }\end{array}$ \\
\hline \multicolumn{4}{|c|}{ Protein metabolism, structure and function } \\
\hline E-06 & 5.43 & 0.015 & $\begin{array}{l}26 \mathrm{~S} \text { proteasome subunit: plays a major role in protein } \\
\text { breakdown. }\end{array}$ \\
\hline E-08 & 2.48 & 0.039 & $\begin{array}{l}\text { Protein domains }{ }^{\mathrm{a}} \text { : (1) Nascent polypeptide-associated complex } \\
\text { protein, reversibly binds ribosomes; (2) ubiquitin-associated } \\
\text { domain }\end{array}$ \\
\hline E-20 & 0.01 & 0.016 & $\begin{array}{l}\text { Cyclophilin: involved in protein folding, can modulate protein } \\
\text { function }\end{array}$ \\
\hline E-24 & 0.09 & 0.035 & $\begin{array}{l}\text { Cyclophilin: involved in protein folding, can modulate protein } \\
\text { function }\end{array}$ \\
\hline E-46 & 0.12 & 0.021 & $\begin{array}{l}\text { Involved in the regulated turnover of proteins important in } \\
\text { cell cycle progression }\end{array}$ \\
\hline \multicolumn{4}{|c|}{ Protein structure and signal transduction } \\
\hline E-69 & 1.85 & 0.006 & Involved in protein folding and signal transduction \\
\hline E-97 & 0.49 & 0.044 & Involved in protein folding and signal transduction \\
\hline \multicolumn{4}{|c|}{ Intracellular signaling } \\
\hline E-64 & 1.88 & 0.035 & $\begin{array}{l}\text { Numerous impacts on intracellular signaling, including: direct } \\
\text { regulation of bound protein; sequestration or modification } \\
\text { of molecules; subcellular localization of bound ligand }\end{array}$ \\
\hline E-93 & 6.80 & 0.015 & $\begin{array}{l}\text { Anchors activated protein kinase C's to subcellular } \\
\text { compartments }\end{array}$ \\
\hline \multicolumn{4}{|c|}{ Lipid transport } \\
\hline E-102 & 0.36 & 0.038 & $\begin{array}{l}\text { Lipocalin family: transports small hydrophobic molecules, } \\
\text { such as lipids, steroid hormones, and retinoids; includes } \\
\text { prostaglandin D synthase }\end{array}$ \\
\hline \multicolumn{4}{|r|}{1} \\
\hline $\mathrm{E}-18$ & 0.11 & 0.000 & $\begin{array}{l}\text { Thioredoxin peroxidase: reduces hydrogen peroxide, } \\
\text { peroxynitrite, and organic hydroperoxides }\end{array}$ \\
\hline \multicolumn{4}{|c|}{$D N A$ replication and repair } \\
\hline E-25 & 0.41 & 0.013 & DUTPase: hydrolyses dUTP to dUMP and pyrophosphate \\
\hline E-41 & 0.26 & 0.000 & $\begin{array}{l}\text { Exact function unknown; able to bind to tubulin in the } \\
\text { cytoskeleton, has a high affinity for calcium, and is induced } \\
\text { in vitamin D-dependent apoptosis }\end{array}$ \\
\hline
\end{tabular}

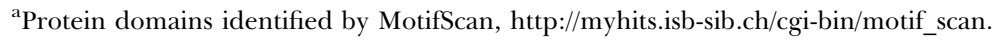




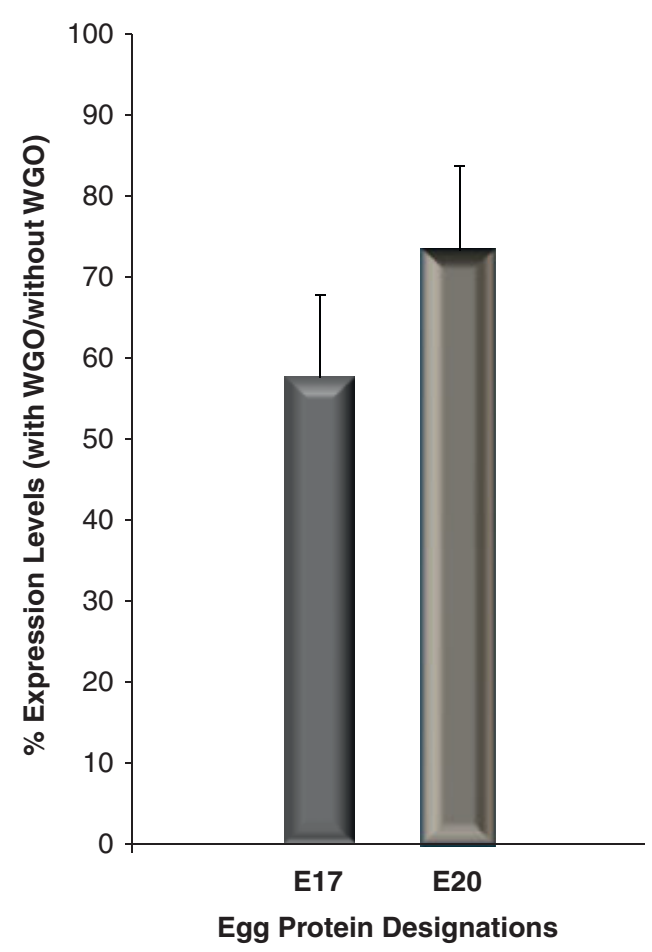

Figure 3. WGO influence on mRNA levels in eggs oviposited by adults from larvae reared on diet with and without WGO. Gene-specific primers were generated based on sequence data from selected proteins and were used to determine mRNA levels using quantitative PCR. Histogram bars represent mean+SE. WGO, wheat germ oil.

from fruit flies reared on WGO-supplemented medium. RACK1 acts in various intracellular signal transduction pathways involving protein kinase C. Because protein kinase $\mathrm{C}$ acts in several signaling pathways, RACK1 is an important component of intracellular signaling. RACK 1 is known from many eucaryotic cells, including insect cells. In the spruce budworm, Choristoneura fumiferana, for example, RACK 1 and protein kinase $\mathrm{C}$ are necessary for the 20-hydroxyecdysone-stimulated expression of a molt-associated transcription factor (Quan et al., 2006). We speculate that one of the subtle effects of essential lipid deficiency, as seen in eggs from fruit flies reared on WGO-lacking medium, is an unseen limitation in signal transduction potential.

Proteins that decreased in expression in $\mathrm{F}_{1}$ eggs by twofold or more as a result of supplementing the larval diet with WGO included two forms of cyclophilin (E-20 and E-24) and thioredoxin (E-18), which facilitate protein folding and isomerization of peptide bonds (Schonbrunner et al., 1991; Berndt et al., 2008), and polyubiquitin (E-46). These proteins are involved with regulating the translocation and degradation of cellular proteins ( $\mathrm{Li}$ and Ye, 2008). We also recorded a decrease in proteins associated with stress or immune functions, including a HSP70-like protein (E-53) and lipocalin (E-102), a transport protein involved with immune response (Flower, 1996), dUTPase (E-25), thought to prevent misincorporation of dUMP into DNA during replication and repair (Chen et al., 2002), and CG4800 (E-41) named a translationally controlled tumor protein but its function is poorly understood (Guillaume et al., 2001). The expression level of five proteins associated with energy and metabolism decreased by twofold or more including three proteins associated with glyceraldehyde-3-phosphate 
dehydrogenase (E-17, E-91, and E-92), best known for its role in glycolysis, a mitochondrial ATPase inhibitor (E-45) involved in decreasing cellular and mitochondrial ATP levels (van Raaij et al., 1996), and malate dehydrogenase (E-52), involved in the citric acid cycle and gluconeogenesis (Minarik et al., 2002). The downregulation of glyceraldehyde-3-phosphate dehydrogenase(s) and malate dehydrogenase suggest that the addition of WGO to the diet leads to reduced carbohydrate metabolism in the fruit fly.

Turning to the protein identification information (Tables 3 and 4), we note high significance levels by MOWSE scores and E-values. We regard this as indication of homology in the part of the sequence related to that functionality of the protein.

Organisms compensate for alterations in nutritional quality to maintain critical homeostasis appropriate to given stages of development and to minimize the impact of the nutritional shortcomings. In our view, the ideal biological markers are associated within the compensation processes (e.g. energy production and cell protection), rather than a major activity associated with a specific developmental stage (e.g. vitellogenesis; Coudron et al., 2006). Hence, we propose that genes in the egg demonstrated pronounced expression level changes, i.e. E-06, E-20, E-24, are appropriate biomarker candidates for additional study.

As we saw for protein L-10, a few other proteins recorded from eggs and larvae were also expressed in adults (Chang et al., 2010). For larvae, L-26, another heat shock protein, corresponds to protein F-40 and F-114, which did not significantly increase in expression in females. For eggs, E-17 agrees with M-53; expression of this protein decreased by about $60 \%$ in eggs and males. E-49 equates to F-06; although expression in eggs did not increase, F-06 increased by about 4-fold in adults reared on diets supplemented with WGO. Egg protein E-52 matches female protein F-46; expression did not change significantly for either developmental stage. E-92 is the same as F-54, expression of which is significantly decreased in eggs and adult females. L-13 matches M-03, which in males reared on WGO-supplemented diets increased by twofold while expression of L-13 decreased by about $40 \%$. Proteins that undergo such excursions in expression over development may be important in identifying biomarkers for nutritional deficiency.

Early stages in larval development may be the preferred stage for discovery of molecular markers for nutritionally deficient culture media because media development decisions could be taken with minimal rearing time and costs. As mentioned earlier, this may be biologically inappropriate if important nutrients are provided in the eggs. Nonetheless, for optimal media development, the $\mathrm{F}_{1}$ egg may be a preferred stage. Egg stages also provide purity of sample, and ease of collection, storage and handling. This has the down-side of rearing insects through to $F_{1}$ eggs before a decision on media quality can be taken. These findings apply to the Oriental fruit fly; with respect to the broader issue of efficiently developing insect culture media, we emphasize the importance of continued research on the use of biomarkers for media development and with other insect species.

\section{ACKNOWLEDGMENTS}

We thank Beverly DaGue, MU Protein Center, for her expert work on mass spectrometry and protein analysis presented in this report, and the technical help from Becky Heinig, Thomas Mangine, Monica Lee in data collection and diet preparation. We also thank Kalle, USA, Inc and Lallemand Bioingredients, Ltd., for 
their generosity in providing sponge cloths and yeast used in this study. Mention of trade names or commercial products in this publication is solely for the purpose of providing specific information and does not imply recommendation or endorsement by the U.S. Department of Agriculture.

\section{LITERATURE CITED}

Beinert H, Kennedy MC, Stout CD. 1996. Aconitase as iron-sulfur protein, enzyme, and ironregulatory protein. Chem Rev 96:2335-2374.

Berndt C, Lillig CH, Holmgren A. 2008. Thioredoxins and glutaredoxins as facilitators of protein folding. Biochim Biophys Acta 1783:641-650.

Chang CL. 2009. Evaluation of yeast products in liquid larval diet for Bactrocera dorsalis and in adult diet for Ceratitis capitata, B. dorsalis, and B. cucurbitae. J Insect Science 9:23.

Chang CL, Caceres C, Jang EB. 2004. A novel liquid larval diet and its rearing system for Melon fly, Bactrocera cucurbitae (Coquillett) (Diptera: Tephritidae). Ann Entomol Soc Am 97:524-528.

Chang CL, Coudron TA, Goodman C, Stanley D, An S, Song Q. 2010. Wheat germ oil in larval diet influences gene expression in adult oriental fruit fly. J Insect Physiol 56: 356-365.

Chang CL, Vargas RI. 2007. Wheat germ oil and its effects on a liquid larval rearing diet for oriental fruit flies (Diptera: Tephritidae). J Econ Entomol 100:322-326.

Chen R, Wang H, Mansky LM. 2002. Roles of uracil-DNA glycosylase and dUTPase in viarus replication. J Gen Virol 83:2339-2345.

Coudron TA, Yocum GD, Brandt SL. 2006. Nutrigenomics: a case study in the measurement of insect response to nutritional quality. Entomol Exp Appl 121:1-14.

Dadd RH. 1985. Nutrition: organisms. In: Kerkut GA, Gilbert LI, editors. Comprehensive insect physiology, biochemistry and pharmacology, vol. 4. Oxford: Pergamon Press. p 313-390.

Fife T, Szabo A. 1973. Cyclic AMP inhibition of reactions of glyceraldehyde-3-phosphate dehydrogenase. Arch Biochem Biophys 157:100-105.

Flower DR. 1996. The lipocalin protein family: structure and function. Biochem J 318:1-14.

Guillaume E, Pineau C, Evrard B, Dupaix A, Moertz E, Sanchez JC, Hochstrasser DF, Jegou B. 2001. Cellular distribution of translationally controlled tumor protein in rat and human testes. Proteomics 7:880-889.

Hershko A, Ciechanover A. 1998. The ubiquitin system. Annu Rev Biochem 67:425-479.

Li W, Ye Y. 2008. Polyubiquitin chains: functions, structures, and mechanisms. Cell Mol Life Sci 65:2397-2406.

Livak KJ, Schmittgen TD. 2001. Analysis of relative gene expression data using the real-time quantitative PCR and the 2(-Delta Delta C(T)) method. Methods 25:402-402.

Minarik P, Tomaskova N, Kollarova M, Antalik M. 2002. Malate dehydrogenases-structure and function. Gen Physiol Biophys 21:257-265.

Parker AG. 2005. Mass-rearing for sterile insect release. In: Dyck VA, Hendrichs J, Robinson AS, editors. Sterile insect technique, principles and practice in area-wide integrated pest management, 2005 IAEA. Amsterdam, The Netherlands: Springer. p 209-232.

Quan GX, Krell PJ, Arif BM, Feng Q. 2006. Receptor of activated C kinase 1 (RACK1) is necessary for the 20-hydroxyecdysone-induced expression of the transcription factor CHR3 in the spruce budworm Chopristoneura fumiferana. Insect Mol Biol 15:79-87.

Schonbrunner, ER, Mayer S, Tropschug M, Fischer G, Takahashi N, Schmid FX. 1991. Catalysis of protein folding by cyclophilins from different species. J Biol Chem 266:3630-3635. 
Stanley DW, Goodman C, An S, McIntosh A, Song Q. 2008. Prostaglandins A1 and E1 influence gene expression in an established insect cell line (BCIRL-HzAM1 cells). Insect Biochem Mol Biol 38:275-284.

van Raaij MJ, Orriss GL, Montgomery MG, Runswick MJ, Fearnley IM, Skehel JM, Walker JE. 1996. The ATPase inhibitor protein from bovine heart mitochondria: the minimal inhibitory sequence. Biochemistry 35:15618-15625.

Wegrzyn RD, Hofmann D, Merz F, Nikolay R, Rauch T, Graf C, Deuerling E. 2006. A conserved motif is prerequisite for the interaction of NAC with ribosomal protein L23 and nacent chains. J Biol Chem 281:2847-2857.

Yocum GD, Coudron TA, Brandt SL. 2006. Differential gene expression in Perillus bioculatus nymphs fed a suboptimal artificial diet. J Insect Physiol 52:586-592. 